\title{
Konya koşullarında bazı kuru fasulye (Phaseolus vulgaris L.) genotiplerinin kalite özelliklerinin belirlenmesi
}

\section{Seydi AYDOĞAN ${ }^{D}$ 1, Mehmet ŞAHIN ${ }^{\circledR 1}$, Aysun GöÇMEN AKÇACIK ${ }^{\circledR}$, Sümeyra HAMZAOĞLU ${ }^{\circledR 1}$, Berat

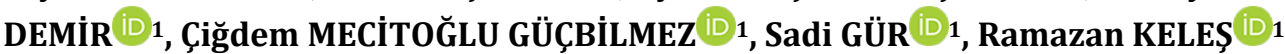

1Bahri Dağdaş Uluslararası Tarımsal Araștırma Enstitüsü, Konya

Alınış tarihi: 14 Ocak 2020, Kabul tarihi: 16 Haziran 2020

Sorumlu yazar: Seydi AYDOĞAN, e-posta: seydiaydogan@yahoo.com

Öz

Dünyada ve ülkemizde bitkisel proteinin ana kaynağını oluşturan yemeklik dane baklagiller, beslenmede oldukça önemli yer tutmaktadır. Bu araştırma 2018 ve 2019 yıllarında 12 farklı kuru fasulye genotipi ile Konya lokasyonunda, tesadüf blokları deneme desenine göre 2 tekerrürlü olarak yıllar ve genotiplerin kalite üzerine etkilerinin araştırılması amacıyla yürütülmüștür. Çalıșma sonucunda, su alma indeksi hariç incelenen diğer özellikler bakımından yıllar ve genotipler arasında $(\mathrm{P}<0.01)$ ve $(\mathrm{P}<0.05) \quad$ seviyesinde istatistiksel anlamda farklılıklar belirlenmiștir. Araştırmada kullanılan fasulye genotiplerinin kalite özelliklerinin ortalama değerleri; nem oranı \% 10.44-11.01, protein oranı \%19.99-22.50, kuru ağırlık (\%14 nem) 29.92-51.54 g, yaș ağırlık 67.32-111.93 g, kuru hacim 76.50-98.50 ml, islak hacim 162.75-188.75 ml, su alma kapasitesi 0.36-0.59 g/tane, şişme kapasitesi 0.36-0.47 ml/tane, şişme indeksi \% 1.85-2.43 ve su alma indeksi \% 1.09-1.18 arasında değişmiştir. İncelenen kalite değerlerine genotip özellikleri ile yıl faktörlerinin etkisinin önemli olduğu tespit edilmiştir.

Anahtar kelimeler: Kuru fasulye, protein, islak hacim, şişme kapasitesi ve indeksi
Determination of quality properties of some dry bean genotypes in Konya conditions

\begin{abstract}
Edible legumes, which constitute the main source of vegetable protein in the world and in our country, have an important place in nutrition. This research was carried out to investigate the effects years and genotypes on quality traits with 12 different dry bean genotypes according to randomized block design with two replications in Konya location in 2018 and 2019 years. As a result of the study, in terms of other studied traits except for the water intake index, statistical differences were determined between years and genotypes at the level of ( $P$ $<0.01)$ and $(P<0.05)$. The average values of quality characteristics of bean genotypes used in the research changed between 10.44-11.01\% for moisture content, $19.99-22.50 \%$ for protein content, 29.92-51.54 g for dry grain weights (14\% moisture), 67.32-111.93 g for wet weights, $76.50-98.50 \mathrm{ml}$ for dry volume, $162.75-188.75 \mathrm{ml}$ for wet volume, 0.36 $0.54 \mathrm{~g} /$ grain for water uptake capacity, $0.36-0.47$ $\mathrm{ml}$ /grain for water swelling capacity, $1.85-2.43 \%$ for swelling index and 1.09-1.18\% for water uptake index. It was determined that genotype properties and year factors had a significant effect on the quality values examined.
\end{abstract}

Key words: Dry bean, protein, wet volume, swelling capacity and index

Aydoğan, S., Şahin, M., Göçmen Akçacık, A., Hamzaoğlu, S., Demir, B.,, Mecitoğlu Güçbilmez, Ç., Gür, S., \& Keleş, R. (2020). Konya koșullarında bazı kuru fasulye (Phaseolus vulgaris L.) genotiplerinin kalite özelliklerinin belirlenmesi. Akademik Ziraat Dergisi, 9(2), 259-270. 


\section{Giriş}

Tarla bitkileri yetiştiriciliğinde ekim alanı ve üretim bakımından önemli yer tutan baklagiller, besin değeri bakımından zengin ve yetiştirildiği toprağa olumlu etkilerinden dolayı oldukça önemlidir. Fasulye temel gıda amaçlı baklagiller arasında dünyada soya ve yerfistı̆̆ından sonra yetiştiriciliği yapılan en önemli üçüncü bitkidir (Fageria ve ark., 2014). Ülkemizde kuru fasulye milli yemeğimiz olup, protein oranı ve tanenin besin içeriğinin önemli bir kalite özelliğine sahip olmasından dolayı beslenmemizde ayrıcalıklı bir yere sahiptir. İşlenmemiş tohumlar doğrudan pişirilerek tüketilebildiği gibi konserve ürünler ya da karışım (glutensiz buğday unu vb.) olarak çeşitli biçimlerde tüketilmektedir (Nciri ve ark., 2015). Tazesi mineraller ve vitaminlerce, kuru tanesi ise proteince zengin bir üründür (Balkaya, 1999). Tahıl proteinlerinde bazı aminoasitlerin sınırlı oranda olması ve hayvansal kaynaklı gidaların birim alan fiyatlarının yüksek oluşu, protein ihtiyacının karşılanmasında yemeklik tane baklagilleri vazgeçilmez bir alternatif konumuna getirmiştir (Şehirali, 1988). Dünya ortalama değerlerine bakıldığında, kişi başına tüketilen miktar çok düşük olup fasulyede $3-4 \mathrm{~kg}$, bezelyede $1 \mathrm{~kg}$ dolaylarında iken; mercimek ve nohutta $1 \mathrm{~kg}$ altındadır (Anonim, 2009a). 2016 yllı itibariyle dünya üzerinde kuru fasulye ekim alanı 29 milyon hektarı geçerken 1.5 milyon hektar da taze fasulye üretimi yapılmıştır. Üretim ise sırasıyla kuru fasulyede 26.8 milyon ton ve taze fasulyede 23.5 milyon tonu geçmiștir (Anonim, 2018). Kuru fasulye üretimi; 2017 üretim döneminde 239 bin ton olarak gerçekleşen Türkiye kuru fasulye üretiminin \% 65.2'si İç Anadolu Bölgesi'nden karşılanmıştır. Konya ili tek başına Türkiye'nin kuru fasulye üretiminin \% 30'unu karşılamıștır. Konya ilinden sonra Karaman ili \%13, Nevşehir ili \%12 ve Niğde ili \% 7.9 ile Türkiye kuru fasulye üretiminden pay almışlardır. Türkiye'de nohut ve mercimekten sonra en çok üretimi yapılan baklagil olan kuru fasulye üretiminde son 5 yllda \% 22'lik bir artış yaşanmıştır(Anonim, 2017). Ekim alanlarındaki daralmaya rağmen üretimde yaşanan artışta verim artışı etkili olmuştur. Üretimdeki artışa rağmen kendine yeterlilik oranının \% 86.2 olması Türkiye'yi ithalata yönlendirmektedir (Bolat, 2016). Ekolojik koşullar bakımından seçiciliği en fazla olan yemeklik tane baklagil bitkilerinden birisi fasulyedir. Fasulyenin su ve besin maddesi ihtiyacı oldukça fazladır ve yetişme süresi boyunca $300-400 \mathrm{~mm}$ toplam suya ihtiyaç duyar. İklime, çevre şartlarına, bitkinin yetiştiği toprak yapısına, kültürel uygulamalara ve çeşide bağlı olarak değişim göstermektedir (Barros ve Prudencio, 2016; Sözen ve ark., 2017). Fasulye bitkisinin suya en hassas olduğu dönemler çiçeklenme, bakla oluşumu ve tane doldurma dönemleridir (Castañeda ve ark., 2006). Fasulye bitkisinde, çiçek oluşumu, tam çiçeklenme, meyve oluşumu ve dane dolum döneminde meydana gelen kuraklık stresi ürün veriminde \% 40-60 oranında kayba neden olmaktadır (Nunez Barrios ve ark., 2005). Tanenin fiziksel kalite özellikleri olarak bilinen kuru tohum ağırlığı, yaş tohum ağırlığı, su alma kapasitesi, su alma indeksi, şişme kapasitesi, şişme indeksi ile teknolojik özellikler olarak bilinen kuru ve ıslak hacim, pişme süresi ve protein oranı gibi özellikler ve beslenme kalitesi üzerine çeşitli çalışmalar yapılmıştır (Montoya ve ark., 2008; Gathu ve Njage, 2012; Barros ve Prudencio, 2016; Ferreira ve ark., 2017). Bu çalışmada ülkemizde baklagillerin yoğun olarak yetiştirildiği Konya ilinde kuru fasulye genotiplerinin kalite özellikleri analiz edilip, ylllar arasındaki farklılıkların kalite üzerine etkilerinin araştırılması ve teknolojik özellikleri bakımından daha iyi olan kaliteli genotiplerin belirlenmesi amaçlanmıştır.

\section{Materyal ve Yöntem}

2018 ve 2019 yılında Bahri Dağdaş Uluslararası Tarımsal Araştırma Enstitüsü Konya merkez lokasyonunda kuru fasulye bölge verim denemesinde (KFBVD) yer alan 10 hat, 2 standart çeşidin (Zirve ve Noyanbey) kalite çalışmaları tesadüf blokları deneme desenine göre iki tekerrürlü olarak yapılmıştır. Denemenin yürütüldüğü 2018 yllında vejetasyon süresinde kaydedilen toplam yağış $140.20 \mathrm{~mm}$ ve ortalama sıcaklık $21.48{ }^{\circ} \mathrm{C}, 2019$ yllında ise $71.00 \mathrm{~mm}$, ortalama sıcaklık $20.86{ }^{\circ} \mathrm{C}$ olmuştur( Çizelge 1). Bölgede vejetasyon döneminde düşen toplam yağış miktarı istenilen ölçüden düşük olduğundan yetiştirme boyunca özellikle çiçeklenme ve bakla oluşum dönemlerinde 6 defa damla sulama yapılmıştır. Tarım ve Orman Bakanlığı Tohumluk Tescil ve Sertifikasyon Merkezi Müdürlüğü'nün Tarımsal Değerleri Ölçme Denemeleri Teknik Talimatı'nda (Anonim, 2001) belirtilen şekilde aşağıdaki teknolojik öğelere ait ölçümler yapılmıştır.

Kuru Ağırlık (g): 100 adet kuru fasulye sayılıp tartıldıktan sonra kuru ağırlık(\%14 nem esasına göre) belirlenmiștir.

Yaş Ağırlık (g): 100 tane tohumun kuru ağırlığı alındıktan sonra üzerine su ilave edilerek 16 saat 
suda bekletildikten sonra su boşaltılmış, sonra kurutma kâğıdı ile kurulanıp tartılarak yaş ağırlık belirlenmiştir.

Su Alma Kapasitesi (g/tane) = (Yaş ağırlık-Kuru ağırlık)/100

Su Alma Indeksi (\%) = Şişme kapasitesi(g/tane)/(Kuru ağırlık/100)

Kuru Hacim (ml):100 tane kuru fasulye numunesi dereceli silindire konulmuş $50 \mathrm{ml}$ saf su ilave edilerek kuru hacim belirlenmiştir.

Islak Hacim (ml): 100 tane kuru fasulye numunesine belirli miktar saf su ilave edilip, 16 saat bekletildikten sonra kağıt havlu ile kurulanarak ölçülü silindire konulmuş ıslak hacim belirlenmiștir.

Şişme Kapasitesi (ml/tane): [[(Islak Hacim-100)(Kuru Hacim-50)]-[((Kuru Hacim-50)/100) ]]/100

Şişme İndeksi (\%): (Islak hacim - 100) /(Kuru hacim - 50)

Protein Oranı (\%): Hasat edilen fasulyelerden $30 \mathrm{~g}$ tohum örneği değirmende öğütülmüș, protein analizi Dumas metoduna göre (LECO FP 528) cihazında yapılmıştır (Anonim, 2009b).

Nem oranı (\%): Örnekler etüvde $105{ }^{\circ} C^{\prime}$ de 4 saat kurutularak, ağırlık (su) kaybını belirleme esası ile nem oranı tespit edilmiştir (Elgün ve ark. 2005). Araștırmada elde edilen veriler JMP 11 istatistik programında tesadüf bloklarında faktöriyel deneme desenine göre varyans analizine tabi tutulmuş elde edilen ortalama değerler arasındaki farklılıklar, student çoklu karşılaştırma testi kullanılarak \%5 önem seviyesinde karşılaştırılmıştır (Anonim, 2014).

\section{Bulgular ve Tartışma}

Bahri Dağdaş Uluslararası Tarımsal Araştırma Enstitüsü Konya-merkez lokasyonunda 2018 ve 2019 yetiştirme döneminde ilkim verileri Çizelge 1'de, genotip pedigrileri Çizelge 2'de ve kalite özelliklerine ait birleştirilmiş varyans analizleri ise Çizelge 3 ve Çizelge 4'de verilmiştir.

\section{Nem Oranı (\%)}

Çizelge 3'ü incelendiğimizde nem oranlarında genotip ve yllar arasında istatiksel olarak $(\mathrm{P}<0.01)$ ve $(\mathrm{P}<0.05) \quad$ seviyesine göre önemli farklılıklar bulunmuştur. Denemelerde ele alınan fasulye çeşit ve hatlarına ait nem oranlarının 2018 yılında \% 10.51-11.30, 2019 yılında ise \% 10.18-10.77 arasında değiștiği tespit edilmiştir. Denemede yer alan 10 hattın ortalaması \% 10.65, standartların ortalaması \% 10.94 ve deneme ortalaması ise \% 10.70 olmuştur(Çizelge 5).

\section{Protein Oranı (\%)}

Kuru fasulye tüm dünyada insan beslenmesine katkı sağlayan önemli bir protein kaynağıdır (Singh, 2001). Çalışmada protein oranı bakımından genotipler $(\mathrm{P}<0.01)$, yllar $(\mathrm{P}<0.05)$ ve genotip*yl interaksiyonu ise $(\mathrm{P}<0.05)$ seviyesinde önemli farklar belirlenmiştir (Çizelge 3). Protein oranları yıllara ve genotiplere göre farklılıklar tespit edilmiş, 2018 yılında protein oranları \% 18.93-22.59 arasında değișmiş, en yüksek değer 7 no'lu hatta, en düşük değer ise Zirve çeşidinden elde edilmiştir.

Çizelge 1. Deneme yıllarına ait iklim değerleri

\begin{tabular}{ccccccccc}
\hline \multirow{2}{*}{ Aylar } & \multicolumn{2}{c}{ Yağıș $(\mathrm{mm})$} & \multicolumn{2}{c}{ Maksimum Sicaklık $\left({ }^{\circ} \mathrm{C}\right)$} & \multicolumn{2}{c}{ Minimum Sıcaklık $\left({ }^{\circ} \mathrm{C}\right)$} & \multicolumn{2}{c}{ Ortalama Sicaklık $\left({ }^{\circ} \mathrm{C}\right)$} \\
\cline { 2 - 9 } & 2018 & 2019 & 2018 & 2019 & 2018 & 2019 & 2018 & 2019 \\
\hline Mayıs & 72.20 & 10.20 & 29.60 & 35.50 & 5.10 & 1.10 & 17.20 & 17.80 \\
Haziran & 38.80 & 45.60 & 34.20 & 33.00 & 7.50 & 6.20 & 21.20 & 20.90 \\
Temmuz & 20.40 & 7.60 & 35.50 & 37.10 & 12.10 & 9.20 & 24.90 & 23.10 \\
Ağustos & 0.80 & 1.20 & 35.50 & 35.90 & 11.30 & 9.70 & 24.30 & 23.30 \\
Eylül & 8.00 & 6.40 & 34.10 & 32.90 & 7.50 & 0.20 & 19.80 & 19.20 \\
\hline Toplam & 140.20 & 71.00 & 33.78 & 34.88 & 8.70 & 5.28 & 21.48 & 20.86 \\
\hline
\end{tabular}

Çizelge 2. Denemede yer alan genotipler(hat/çeşit)

\begin{tabular}{cccc}
\hline Sira No & Pedigri & Sira No & Pedigri \\
\hline 1 & ÜKFAM2014-107 SAM 185BD & 7 & ÜKFAM2014-125 SAM 272BD \\
2 & ÜKFAM2014-107 SAM 186BD & 8 & ÜKFAM2014-126 SAM 285BD \\
3 & ÜKFAM2014-113 SAM 219BD & 9 & ÜKFAM2014-126 SAM 286BD \\
4 & ÜKFAM2014-117 SAM 232BD & 10 & ÜKFAM2014-126 SAM 287BD \\
5 & ÜKFAM2014-117 SAM 233BD & 11 & ZİRVE \\
6 & ÜKFAM2014-123 SAM 261BD & 12 & NOYANBEY \\
\hline
\end{tabular}


Çizelge 3. Kuru fasulye genotiplerinin(hat/çeşit) incelenen kalite özelliklerine ait birleştirilmiş varyans analizleri

\begin{tabular}{ccccccc}
\hline Kaynak & SD & Nem Oranı & Protein Oranı & Kuru Ağırlık & Kuru Hacim & Yaș Ağırlık \\
\hline Genotip & 11 & $1.3683667^{* *}$ & $34.984545^{* *}$ & $1401.0781^{* *}$ & $1478.2292^{* *}$ & $6567.6076^{* *}$ \\
Yll & 1 & $1.2416333^{*}$ & $4.589889^{*}$ & $773.0299^{* *}$ & $513.5208^{* *}$ & $3740.9180^{* *}$ \\
Tekerür & 1 & 0.0016333 & 0.000554 & 19.3979 & 20.0208 & 162.0308 \\
Genotip*Yıl & 11 & 0.9023667 & $13.117517^{*}$ & 190.1406 & 118.7292 & 1004.8938 \\
Hata & 23 & 1.1617667 & 7.597307 & 1401.0781 & 210.4792 & 1468.413 \\
$\mathrm{R}^{2}$ & & 0.751535 & 0.873987 & 0.906763 & 0.910089 & 0.886555 \\
$\mathrm{DK}_{(\%)}$ & & 2.05 & 2.68 & 6.32 & 3.51 & 6.87 \\
AOOF$_{(0.05)}$ & & 0.32 & 0.83 & 4.73 & 4.38 & 11.63 \\
\hline Genel Ortalama & & 10.70 & 21.27 & 40.67 & 86.08 & 90.46 \\
\hline
\end{tabular}

Çizelge 4. Kuru fasulye genotiplerinin(hat/çeşit) incelenen kalite özelliklerine ait birleştirilmiş varyans analizleri

\begin{tabular}{ccccccc}
\hline Kaynak & SD & Islak Hacim & Su Alma Kapasitesi & Șișme Kapasitesi & Șișme İndeksi & Su Alma İndeksi \\
\hline Genotip & 11 & $2906.5625^{* *}$ & $0.05709064^{*}$ & $0.17755498^{* *}$ & $1.1078325^{*}$ & 0.03674356 \\
Yll & 1 & $1210.0208^{* *}$ & $0.01483024^{*}$ & $0.10239224^{* *}$ & $0.1895887^{*}$ & 0.00210094 \\
Tekerür & 1 & 6.0208 & 0.00039418 & 0.00598165 & 0.0433145 & 0.00274168 \\
Genotip*Yll & 11 & 237.2292 & 0.01687416 & 0.03611798 & 0.3836624 & 0.04314955 \\
Hata & 23 & 802.4792 & 0.04959868 & 0.05793775 & 0.6607496 & 0.06347 \\
R $^{2}$ & & 0.84455 & 0.64263 & 0.847526 & 0.722973 & 0.571727 \\
KK$_{(\%)}$ & & 3.33 & 6.14 & 6.09 & 6.86 & 2.65 \\
AÖF(0.05) & & 8.59 & 0.07 & 0.06 & 0.24 & 0.03 \\
\hline Genel Ortalama & 177.41 & 0.48 & 0.41 & 2.18 & 1.15 \\
\hline
\end{tabular}

Çizelge 5. Genotiplerin(hat/çeşit) nem oranı, protein oranı ve kuru ağırlığına ait değerler

\begin{tabular}{cccccccccc}
\hline \multirow{2}{*}{ Genotipler(Hat/Çeșit) } & \multicolumn{3}{c}{ Nem Oranı (\%) } & \multicolumn{3}{c}{ Protein Oranı (\%) } & \multicolumn{3}{c}{ Kuru Ağırlı (g) $\% 14)$} \\
\cline { 2 - 9 } & 2018 & 2019 & Ortalama & 2018 & 2019 & Ortalama & 2018 & 2019 & Ortalama \\
\hline 1 & 10.61 & 10.75 & 10.68 & 21.83 & 23.03 & 22.43 & 41.25 & 48.39 & 44.82 \\
2 & 10.51 & 10.37 & 10.44 & 22.15 & 21.34 & 21.74 & 40.70 & 43.62 & 42.16 \\
3 & 10.95 & 10.76 & 10.85 & 20.64 & 19.97 & 20.30 & 31.90 & 38.49 & 35.19 \\
4 & 10.65 & 10.49 & 10.57 & 21.69 & 22.68 & 22.19 & 39.05 & 44.29 & 41.67 \\
5 & 10.89 & 10.40 & 10.64 & 22.01 & 22.07 & 22.04 & 41.20 & 48.21 & 44.70 \\
6 & 11.05 & 10.77 & 10.91 & 21.23 & 20.64 & 20.93 & 35.15 & 40.09 & 37.62 \\
7 & 10.53 & 10.48 & 10.50 & 22.59 & 22.42 & 22.50 & 39.35 & 50.02 & 44.69 \\
8 & 10.75 & 10.66 & 10.70 & 20.18 & 21.70 & 20.94 & 44.80 & 58.29 & 51.54 \\
9 & 10.92 & 10.18 & 10.55 & 19.32 & 21.75 & 20.53 & 35.15 & 45.37 & 40.26 \\
10 & 11.00 & 10.38 & 10.69 & 19.87 & 20.77 & 20.32 & 28.85 & 30.99 & 29.92 \\
Zirve & 10.78 & 10.52 & 10.65 & 21.15 & 21.64 & 21.39 & 37.74 & 44.78 & 41.26 \\
Hatlar Ortalaması & 11.20 & 10.53 & 10.87 & 18.93 & 21.06 & 19.99 & 28.15 & 44.09 & 36.12 \\
Noyanbey & 11.30 & 10.73 & 11.01 & 21.07 & 21.45 & 21.26 & 33.80 & 43.82 & 38.81 \\
Standartlar Ort. & 11.25 & 10.63 & 10.94 & 20.00 & 21.26 & 20.63 & 30.98 & 43.96 & 37.47 \\
\hline Genel Ortalama & 10.85 & 10.54 & 10.70 & 20.97 & 21.58 & 21.27 & 36.70 & 44.65 & 40.67 \\
\hline
\end{tabular}

Denemede yer alan 10 hattın ortalama protein oranı $\%$ 21.15, standartların ortalaması \% 20.00, deneme ortalaması \% 20.97 olmuş ve genotiplerin protein oranlarının standart çeşitler ve deneme ortalamasına göre daha yüksek olduğu tespit edilmiştir. Protein oranları gübreleme, sulama, iklim ve toprak yapısına göre değişiklik göstermektedir (Akçin, 1988). 2019 yılında protein oranı \% 19.9723.03 arasında değişmiş, en yüksek değer 1 no'lu hatta, en düşük değer ise 3 no'lu hatta belirlenmiştir. Denemede yer alan 10 hattın ortalama protein oranı
$\%$ 21.64, standartların ortalaması \% 21.26, deneme ortalaması ise \% 21.58 olmuş ve hatların protein oranlarının standart çeşitlerden ve deneme ortalamasından daha yüksek olduğu tespit edilmiştir. İki yılın protein oranı ortalamasına göre 1 no'lu hat \% 22.43 ile en yüksek değeri almış, en düşük değer \% 20.30 ile 3 no'lu hatta belirlenmiş ve hatların protein oranları standart çeşitler ve deneme ortalamasından yüksek olmuştur. Noyanbey çeșidinin protein oranı her iki yılda da Zirve çeşidine göre daha yüksek olmuştur. Kuru fasulye ile yapılan 
çalışmalarda tane protein oranının Kahraman (2008) \%20.11-28.59, Ülker (2008) \% 19.51-26.60, Karaca (2010) \%20.78-26.27, Özbekmez (2015) \%18.5026.64 arasında değiştiğini bildirmişlerdir. Cengiz ve ark. (2008), iki yll süreyle iki lokasyonda fasulye çeşitleri ile yürüttükleri bir çalışmada protein oranının \% 19.25-23.66 arasında değiştiğini, çeşit, yetiștirme yeri ve yllının kuru fasulyelerin protein oranı üzerinde çok etkili olduğunu belirlemişlerdir.

\section{Kuru Ağırlık (g)}

Tane iriliği diğer tahıl ürünlerinde olduğu gibi verimi etkileyen önemli bir faktör olup pazar değeri bakımından da büyük taneli çeşitler tercih edilmektedir. Denemelerde ele alınan fasulye çeşit ve hatlarının \% 14 nem esasına göre kuru ağırlıkları yıllara göre farklılıklar göstermiştir (Çizelge 5). 2018 yılında kuru ağırlık 28.15-44.80 g arasında değişmiş, en yüksek değer 8 no' lu hattan, en düşük değer ise Zirve çeşidinden elde edilmiştir. Denemede yer alan 10 hattın ortalama kuru ağırlıkları $37.74 \mathrm{~g}$, standartların ortalaması 30.98 , deneme ortalaması ise $36.70 \mathrm{~g}$ olmuş ve hatların kuru ağırlığının standart çeşitler ve deneme ortalamasından yüksek olduğu belirlenmiştir. Bozoğlu ve Gülümser (1998), kuru fasulyede verim ve bazı verim karakterlerinin genotip $\mathrm{x}$ çevre interaksiyonlarını belirlemek amacıla 4 lokasyon, 2 yıl ve 14 genotip ile yapılan çalışma sonucunda, yemeklik tane baklagillerde verimi ve pazar kalitesini etkileyen en önemli kriterlerden olan 100 tane ağırlı̆̆ının, çeşit, çevre ve bunların interaksiyonundan $\% \quad 1$ olasılıkla etkilendiğini tespit etmişlerdir. Çizelge 3'de görüldüğü gibi kuru ağırlık bakımından genotip ve yıllar arasında istatiksel olarak $(\mathrm{P}<0.01)$ seviyesinde önemli farklar belirlenmiștir. 2019 yılında kuru ağırlık 30.99-58.29 g arasında değişmiş, en yüksek değer 8 no'lu hattan, en düşük değer ise 10 no'lu hattan elde edilmiştir. Denemede yer alan 10 hattın ortalama kuru ağırlı̆̆ $44.78 \mathrm{~g}$, standartların ortalaması $43.96 \mathrm{~g}$ ve deneme ortalaması ise $44.65 \mathrm{~g}$ olmuştur. Denemede yer alan hatların kuru ağırlığının standart çeşitlerden ve deneme ortalamasından yüksek olduğu tespit edilmiştir. İki yıl ortalamasına göre 8 no'lu hat $51.54 \mathrm{~g}$ ile en yüksek değeri almış, en düşük değer ise $29.92 \mathrm{~g}$ ile 10 no'lu hattan elde edilmiştir. Kuru ağırlık yıllara göre farklılık göstermiş; 2018 yılında $36.70 \mathrm{~g}$, 2019 'da ise $44.65 \mathrm{~g}$ olmuş kuru ağırlıklar her iki yılda genotiplere göre farklılık göstermiş, 2019 yılında maksimum ve minimum sicaklık değerleri 2018 yılına göre düşük olmuştur. Genotiplerin 2019 yllında sıcaklık stresinden etkilenmediği, yeterli sıcaklık ve nem oranının nişasta dolum süresi ve tane iriliğini artırdığı düşünülmektedir. Yüz tane ağırlığına genotipin etkisi yüksek olsa da çevre şartlarından da önemli ölçüde etkilenmektedir (Şehirali ve ark., 1994). Cengiz ve ark. (2008), benzer bir çalışmada fasulye çeşitlerinin kuru ağırlıklarının 16.7-52.3 g arasında değiştiğini belirlemişlerdir. Kaçar ve ark. (2004), araştırmalarının 1. yllında çeșitlerin $51.7 \mathrm{~g}$ olan kuru ağırlı ortalamasının, çalışmalarının kurak ve sıcak geçen 2. yılında 37.3 g'a gerilediğini tespit etmişlerdir.

Çizelge 6. Kuru fasulye genotiplerinin(hat/çeşit) tespit edilen kuru hacim, ıslah hacim ve yaş ağırlığına ait değerler

\begin{tabular}{cccccccccc}
\hline \multirow{2}{*}{ Genotipler(Hat/Çeşit) } & \multicolumn{3}{c}{ Kuru Hacim (ml) } & \multicolumn{3}{c}{ Islak Hacim (ml) } & \multicolumn{3}{c}{ Yaș Ağırlık (g) } \\
\cline { 2 - 10 } & 2018 & 2019 & Ortalama & 2018 & 2019 & Ortalama & 2018 & 2019 & Ortalama \\
\hline 1 & 88.00 & 94.50 & 91.25 & 183.00 & 194.00 & 188.50 & 93.05 & 108.41 & 100.73 \\
2 & 84.50 & 89.00 & 86.75 & 177.50 & 186.00 & 181.75 & 90.64 & 99.27 & 94.96 \\
3 & 76.50 & 83.00 & 79.75 & 163.50 & 172.00 & 167.75 & 72.31 & 85.79 & 79.05 \\
4 & 85.00 & 89.00 & 87.00 & 176.00 & 183.00 & 179.50 & 84.48 & 95.90 & 90.19 \\
5 & 85.50 & 91.50 & 88.50 & 180.00 & 186.00 & 183.00 & 92.40 & 109.58 & 100.99 \\
6 & 81.50 & 85.00 & 83.25 & 172.00 & 177.00 & 174.50 & 76.96 & 89.11 & 83.03 \\
7 & 83.50 & 91.50 & 87.50 & 174.50 & 189.50 & 182.00 & 87.85 & 113.54 & 100.69 \\
8 & 92.50 & 104.50 & 98.50 & 183.50 & 194.00 & 188.75 & 98.32 & 125.55 & 111.93 \\
9 & 87.50 & 90.00 & 88.75 & 172.00 & 182.00 & 177.00 & 80.14 & 97.47 & 88.80 \\
10 & 74.50 & 78.50 & 76.50 & 160.50 & 165.00 & 162.75 & 65.93 & 68.71 & 67.32 \\
Hatlar Ortalaması & 83.90 & 89.65 & 86.78 & 174.25 & 182.85 & 178.55 & 84.21 & 99.33 & 91.77 \\
Zirve & 74.50 & 87.50 & 81.00 & 165.50 & 179.50 & 172.50 & 61.50 & 99.97 & 80.74 \\
Noyanbey & 79.50 & 87.60 & 83.50 & 159.50 & 180.00 & 169.75 & 74.75 & 96.91 & 85.83 \\
Standartlar Ortalama & 77.00 & 87.50 & 82.25 & 162.50 & 179.75 & 171.13 & 68.13 & 98.44 & 83.28 \\
\hline Genel Ortalama & 82.84 & 89.32 & 86.08 & 172.44 & 182.37 & 177.41 & 81.73 & 99.19 & 90.46 \\
\hline
\end{tabular}




\section{Kuru Hacim (ml)}

Kuru hacim değerleri kuru ağırlığına bağlı olarak değişmekte olup, 2018 yılında kuru hacim 74.50$92.50 \mathrm{ml}$ arasında değișmiș, en yüksek değer 8 no'lu hattan, en düşük değer ise 10 no'lu hat ve Zirve çeşidinden elde edilmiştir. Denemede yer alan 10 hattın ortalama kuru hacmi $83.90 \mathrm{ml}$, standartların ortalaması $77.00 \mathrm{ml}$ ve deneme ortalaması ise 82.84 ml olmuştur (Çizelge 6). Denemede kuru ağırlıkları yüksek olan hatların kuru hacim ortalamasının da yüksek olduğu tespit edilmiş, genotip ve yllar arasında istatiksel olarak $(\mathrm{P}<0.01)$ seviyesinde önemli farklar tespit edilmiștir (Çizelge 3). Şehirali ve Atlı (1993), fasulye ile yapmış olduğu bir çalışmada kuru ağırlık ile kuru hacim arasında yüksek korelasyon olduğunu ortaya koymuşlardır. Bu çalışmada kuru ağırlık ile kuru hacim arasında $\left(0.9510^{* *}\right)$ pozitif yüksek korelasyon değeri elde edilmiştir (Çizelge 9). 2019 yllında kuru hacim 78.50-104.50 ml arasında değişmiş, en yüksek değer 8 no'lu hatta, en düşük değer ise 10 no'lu hatta belirlenmiştir. Denemede yer alan 10 hattın ortalama kuru hacmi $89.65 \mathrm{ml}$, standartlarm ortalaması $87.50 \mathrm{ml}$, deneme ortalaması $89.32 \mathrm{ml}$ olmuş, genotiplerin kuru hacim değerinin standart çeşitler ve deneme ortalamasından yüksek olduğu tespit edilmiştir. İki yılın ortalamasına göre 8 no'lu hat $98.50 \mathrm{ml}$ ile en yüksek değeri almış, en düşük değer ise $76.50 \mathrm{ml}$ ile 10 no'lu hatta belirlenmiștir. Denemede yer alan hatların kuru hacim ortalaması, standartlar ve deneme ortalamasından yüksek olmuştur. Çalışmamızda kuru hacim yıllara göre farklılık göstermiş; 2018 yılında $82.84 \mathrm{ml}$, 2019'da ise $89.32 \mathrm{ml}$ olmuş, 2019 yllında sıcaklık değerlerinin 2018 yılına göre düşük olması danenin sıcaklık stresinden etkilenmeden dolumunu devam ettirmesini, buna bağlı olarak kuru ağırlık ve kuru hacim değerlerinin daha yüksek olmasını sağlamıştır.

\section{Islak Hacim (ml)}

2018 yılında islak hacim 159.50-183.50 ml arasında değişmiş, en yüksek değer 8 no'lu hatta, en düşük değer ise Noyanbey çeşidinde tespit edilmiştir. Denemede yer alan 10 hattın ortalama islak hacmi $174.25 \mathrm{ml}$, standartların ortalaması $162.50 \mathrm{ml}$ ve deneme ortalaması ise $172.44 \mathrm{ml}$ olarak belirlenmiştir. Hatların islak hacim ortalaması, standart çeşitler ve deneme ortalamasından daha yüksek olmuștur. Islak hacim bakımından genotip ve yllar arasında istatiksel olarak $(\mathrm{P}<0.01)$ seviyesinde önemli farklar tespit edilmiştir (Çizelge 4). 2019 yllında islak hacim 165.00-194.00 $\mathrm{ml}$ arasında değişmiş, en yüksek değer 1 ve 8 no'lu hattan, en düşük değer ise 10 no'lu hattan elde edilmiştir. Denemede yer alan 10 hattın ortalama islak hacmi $182.85 \mathrm{ml}$, standartların ortalaması $179.75 \mathrm{ml}$ ve deneme ortalaması ise $182.37 \mathrm{ml}$ olmuştur. Hatların ıslak hacim ortalamasının standart çeşitler ve deneme ortalamasından yüksek olduğu tespit edilmiştir. İki yıl ortalamasına göre 8 no'lu hat $188.75 \mathrm{ml}$ ile en yüksek değeri almış, en düşük değer ise $162.75 \mathrm{ml}$ ile 10 no'lu hattan elde edilmiştir. Denemede standart olarak kullanılan çeşitlerde en yüksek ıslak hacim 2018 yllında Zirve çeșidinde, 2019 yılında Noyanbey çeșidinde elde edilmiştir. Çalışmamızda ıslak hacim yıllara göre farklılık göstermiş; 2018 yllında $172.44 \mathrm{ml}, 2019$ 'da ise $182.37 \mathrm{ml}$ olmuş, iklim değerlerine ve genotiplere bağlı olarak değişmiştir.

\section{Yaş Ağırlık (g)}

Yaş ağırlık bakımından genotipler ve yıllar arasında istatiksel olarak $(\mathrm{P}<0.01)$ önemli farklar belirlenmiştir (Çizelge 3). 2018 yılında yaş ağırlık 61.50-98.32 g arasında değişmiş, en yüksek değer 8 no'lu hatta, en düşük değer ise Zirve çeşidinde belirlenmiştir. Denemede yer alan 10 hattın ortalama yaş ağırlığı $84.21 \mathrm{~g}$, standartların ortalaması $68.13 \mathrm{~g}$ ve deneme ortalaması ise $81.73 \mathrm{~g}$ olmuştur. Hatların yaş ağırlı̆̆ı ortalamasının, standart çeşitler ve deneme ortalamasından yüksek olduğu tespit edilmiştir. 2019 yllında genotiplerin yaş ağırlığı 68.71-125.55 g arasında değişmiş, en yüksek değer 8 no'lu hatta, en düşük değer ise 10 no'lu hatta elde edilmiştir. Denemede yer alan 10 hattın ortalama yaş ağırlığı $99.33 \mathrm{~g}$, standartların ortalaması $98.44 \mathrm{~g}$ ve deneme ortalaması ise $99.19 \mathrm{~g}$ olmuştur. Hatların yaş ağırlık ortalamasının, standart çeșitler ve deneme ortalamasından yüksek olduğu tespit edilmiştir. İki yıl ortalamasına göre en yüksek değer 111.93 g ile 8 no'lu hatta, en düşük değer ise $67.32 \mathrm{~g}$ ile $10 \mathrm{no}$ 'lu hatta elde edilmiștir. Çalışmamızda yaş ağırlık yıllara göre farklılık göstermiş; 2018 yılında 81.73 g, 2019 yllında ise 99.19 g olmuştur. Kuru hacim değeri yüksek olan genotiplerin taneleri daha iri olmakta, buna bağlı olarak nişasta oranının artması ile tanenin su alması da artmakta olup 2019 yllındaki genotiplerin islak hacim değerleri yüksek olmuștur. Wani ve ark. (2017), karbonhidrat içeriği ile şişme kapasitesi ( $\mathrm{r}=$ $0.794, \mathrm{p}<0.01)$ ve su alma kapasitesi $(r=0.821$, $\mathrm{p}<0.01$ ) arasinda anlamlı pozitif korelasyon belirlemişlerdir. Bu korelasyonun karbonhidratların 
daha fazla su emilimi sağlamasına bağlanabileceğini belirtmişlerdir. Çalışkan ve ark. (2018), yapmış oldukları bir çalışma sonucunda yaş ağırlık ortalamalarının tane iriliklerine göre değiștiğini, tane iriliği arttıkça su alma kapasitesi artacağından, tane iriliğinin yüksek olduğu çeşitlerde yaş ağırlık değerlerin de yüksek olduğunu belirtmişlerdir.

\section{Su Alma Kapasitesi (g/tane)}

Tanenin önemli özelliklerinden birisi olan su alma kapasitesi, hem pişmeyi hem de tanenin su almasıyla meydana gelen irileşmeyi belirlemektedir. Su alma kapasitesi bakımından genotip ve yıllar arasında istatiksel olarak $(\mathrm{P}<0.05)$ önemli farklar belirlenmiştir (Çizelge 4). 2018 yılında su alma kapasitesi 0.33-0.52 g/tane arasında değișmiș, en yüksek değer 8 no'lu hatta en düșük değer ise Zirve çeşidinde elde edilmiş, hatların ortalama su alma kapasitesi $0.45 \mathrm{~g} /$ tane, standartların ortalaması 0.36 $\mathrm{g} /$ tane ve deneme ortalaması ise $0.44 \mathrm{~g} /$ tane olmuştur. 2018 yılında hatların su alma kapasitesinin standart çeşitler ve deneme ortalamasından yüksek olduğu tespit edilmiștir.
Tohumun su alma kapasitesi tohum büyüklüğü ile doğrudan ilişkilidir (Kınacı ve ark., 2008). Çalışmada su alma kapasitesi ile kuru ağırlık arasında $\left(0.9614^{* *}\right)$ pozitif önemli korelasyon değerleri elde edilmiştir (Çizelge 9). 2019 yılında genotiplerin su alma kapasitesi 0.37-0.66 g/tane arasında değişmiş, en yüksek değer 8 no'lu hatta, en düşük değer ise 10 no'lu hatta elde edilmiştir. Denemede yer alan 10 hattın ortalama su alma kapasitesi $0.53 \mathrm{~g} /$ tane, standartlar ve deneme ortalaması ise $0.52 \mathrm{~g} /$ tane olarak belirlenmiştir. İki yıl ortalamasına göre 8 no'lu hat $0.59 \mathrm{~g} /$ tane ile en yüksek değeri almış, en düşük değer ise $0.36 \mathrm{~g} /$ tane ile 10 no'lu hatta elde edilmiştir. Çeşitler arasında Noyanbey çeşidinin su alma kapasitesi her iki yılda da Zirve çeşidinden daha yüksek değere sahip olmuştur. Çalışmamızda su alma kapasitesi yıllara göre farklılık göstermiş; 2018 yllında $0.44 \mathrm{~g} /$ tane, 2019 yllında ise 0.53 $\mathrm{g} /$ tane olmuştur. Tane iriliğinin artması su alma kapasitesini de artırmakta olup 2019 yılında kuru ağırlıkları yüksek olan genotiplerin su alma kapasitesi değerleride daha yüksek olmuştur.

Çizelge 7. Kuru fasulye genotiplerinin (hat/çeşit) su alma kapasitesi ve şişme kapasitesine ait değerler

\begin{tabular}{|c|c|c|c|c|c|c|}
\hline \multirow{2}{*}{ Genotipler (Hat/Çeşit) } & \multicolumn{3}{|c|}{ Su Alma Kapasitesi (g/tane) } & \multicolumn{3}{|c|}{ Șișme Kapasitesi (ml/tane) } \\
\hline & 2018 & 2019 & Ortalama & 2018 & 2019 & Ortalama \\
\hline 1 & 0.50 & 0.59 & 0.54 & 0.45 & 0.50 & 0.47 \\
\hline 2 & 0.49 & 0.52 & 0.50 & 0.43 & 0.47 & 0.45 \\
\hline 3 & 0.39 & 0.46 & 0.43 & 0.37 & 0.39 & 0.38 \\
\hline 4 & 0.44 & 0.50 & 0.47 & 0.41 & 0.44 & 0.43 \\
\hline 5 & 0.50 & 0.60 & 0.55 & 0.45 & 0.44 & 0.44 \\
\hline 6 & 0.42 & 0.48 & 0.45 & 0.41 & 0.42 & 0.41 \\
\hline 7 & 0.47 & 0.62 & 0.54 & 0.41 & 0.48 & 0.45 \\
\hline 8 & 0.52 & 0.66 & 0.59 & 0.41 & 0.40 & 0.40 \\
\hline 9 & 0.46 & 0.51 & 0.48 & 0.35 & 0.42 & 0.38 \\
\hline 10 & 0.36 & 0.37 & 0.36 & 0.36 & 0.37 & 0.36 \\
\hline Hatlar Ortalaması & 0.45 & 0.53 & 0.49 & 0.40 & 0.43 & 0.42 \\
\hline Zirve & 0.33 & 0.55 & 0.44 & 0.41 & 0.42 & 0.42 \\
\hline Noyanbey & 0.40 & 0.52 & 0.46 & 0.30 & 0.43 & 0.36 \\
\hline Standartlar Ortalama & 0.36 & 0.52 & 0.45 & 0.36 & 0.42 & 0.39 \\
\hline Genel Ortalama & 0.44 & 0.52 & 0.48 & 0.40 & 0.43 & 0.41 \\
\hline
\end{tabular}

\section{Şişme Kapasitesi (ml/tane)}

Şişme kapasitesi ağırlık olarak verilen değerlerin hacimsel olarak belirlenmesidir. Yapılan çalışmada şişme kapasitesi genotipler ve yıllar arasında $(\mathrm{P}<0.01)$ önemli farklılıklar göstermiștir. 2018 yılında şişme kapasitesi $0.30-0.45 \mathrm{ml} /$ tane arasında değișmiş, en yüksek oran 1 ve 5 no'lu hatlarda, en düşük değer ise Noyanbey çeşidinde belirlenmiştir. Denemede yer alan 10 hattın ortalama şişme kapasitesi $0.40 \mathrm{ml} /$ tane, standartların ortalaması $0.36 \mathrm{ml} /$ tane ve deneme ortalaması $0.40 \mathrm{ml} /$ tane olarak belirlenmiştir. Hatların şişme kapasitesi standart çeşitler ortalamasından yüksek olmuştur. 2019 yılında şişme kapasitesi 0.37-0.50 ml/tane arasında değişmiş en yüksek oran 1 no'lu hatta, en düşük değer ise 10 no'lu hatta elde edilmiş, hatların ortalama şişme kapasitesi $0.43 \mathrm{ml} /$ tane, standartların ortalaması $0.42 \mathrm{ml} /$ tane ve deneme ortalaması $0.43 \mathrm{ml} /$ tane olarak tespit edilmiştir. İki yıl ortalamasına göre 1 no'lu hat $0.47 \mathrm{ml} /$ tane ile en yüksek değeri almış, en düşük değer ise $0.36 \mathrm{ml} /$ tane ile 10 no'lu hat ve Noyanbey çeşidinden elde 
edilmiştir. Özbekmez (2015), bazı kuru fasulye çeșit ve genotiplerinin teknolojik özelliklerinin belirlendiği bir çalışmasında şişme kapasitesinin 0.104-0.574 ml/tane değiştiğini belirtmiştir. Saha ve ark. (2009), Wani ve ark. (2017) farklı fasulye çeşitlerinde şişme kapasitesini sırasıyla 0.30 - 0.56 $\mathrm{ml} /$ tane, $0.09-0.28 \mathrm{ml} /$ tane olarak belirlemişlerdir. Şişme kapasitesi ile kuru ağırlık arasında (0.5075*) önemli pozitif korelasyon belirlenmiştir (Çizelge 9). Çalışmamızda şişme kapasitesi yıllara göre farklılık göstermiş; 2018 yllında $0.40 \mathrm{ml} /$ tane, 2019 yllında ise $0.43 \mathrm{ml} /$ tane olmuştur.

\section{Şişme İndeksi(\%)}

Şişme indeksi şişen tanelerin hacimlerinin kuru hacimlerine göre ne kadar arttığını göstermektedir. Şişme indeksi bakımından yıl ve genotipler arasında istatiksel olarak $(\mathrm{P}<0.05)$ önemli farklar belirlenmiştir (Çizelge 4). 2018 yllında şişme indeksi \% 1.71-2.46 arasında değişmiş, en yüksek oran 8 no'lu genotip, en düşük değer ise 10 no'lu hatta elde edilmiştir. Denemede yer alan 10 hattın ortalama şişme indeksi \% 2.07, standartların ortalaması \% 1.72 ve deneme ortalaması ise \% 2.01 olmuştur. 2019 yılında şişme indeksi \% 1.82-2.55 arasında değişmiş, en yüksek değer 8 no'lu hatta, en düşük değer ise 3 no'lu hattan elde edilmiştir. Denemede yer alan 10 hattın ortalama şişme indeksi \% 2.28 standartların ortalaması $\% 2.23$ ve deneme ortalaması ise \% 2.27 olarak belirlenmiştir. İki yıl ortalamasına göre Zirve çeşidi Noyanbey çeşidinden daha yüksek değere sahip olmuştur. Çalışmamızda şişme indeksi ylllara göre farklılık göstermiş; 2019 yılında \% 2.01, 2019 yllında ise şişme indeksi \% 2.27 olmuştur. Farklı fasulye çeşitleri ile yapılan çalışmalarda şişme indeksinin Saha ve ark. (2009), \% 0.91-1.39, Wani ve ark. (2017) \% 0.30-0.82 arasında değiştiğini tespit etmişlerdir. Özbekmez (2015), benzer bir çalışmada kuru fasulye genotiplerinde şişme indeksinin $\% 0.468$ ile $\% 2.581$ arasında değiştiğini belirtmiştir.

\section{Su Alma İndeksi (\%)}

Su alma indeksi tanenin kuru ağırlı̆̆ına göre yüzde olarak ne kadar su aldığını ifade etmektedir. Su alma indeksi bakımından yıllar ve genotipler arasında istatiksel olarak önemli farklılıklar tespit edilmemiştir (Çizelge 4). 2018 yllında genotiplerin su alma indeksi \% 1.13-1.29 arasında değişmiş, en yüksek değer 9 no'lu hatta, en düşük değer ise 4 no'lu hatta elde edilmiştir. Denemede yer alan 10 hattın ortalama su alma indeksi \% 1.20, standartların ortalaması $\% 1.17$ ve deneme ortalaması \% 1.20 olmuştur. 2019 yılında genotiplerin su alma indeksi \% 1.11-1.24 arasinda değişmiş, en yüksek değer 5 ve 7 no'lu hatta, en düşük değer ise 9 no'lu hatta elde edilmiştir. Denemede yer alan 10 hattın ortalama su alma indeksi \% 1.18, standartların ortalaması \%1.21 ve deneme ortalaması \% 1.19 olmuştur. İki yll ortalamasına göre en yüksek değer \% 1.23 ile 5 no'lu hat, en düşük değer ise \% 1.13 ile 4 no'lu hatta belirlenmiş̧ir. Çalışmamızda su alma indeksi yıllara göre farklılık göstermiş; 2018 yllında \% 1.20, 2019 yllında ise $\% 1.19$ olarak belirlenmiştir.

Çizelge 8. Kuru fasulye genotiplerinin(hat/çeşit) tespit edilen şişme indeksi ve su alma indeksine ait değerler

\begin{tabular}{|c|c|c|c|c|c|c|}
\hline \multirow{2}{*}{ Genotipler (Hat/Çeşit) } & \multicolumn{3}{|c|}{ Şişme İndeksi(\%) } & \multicolumn{3}{|c|}{ Su Alma İndeksi(\%) } \\
\hline & 2018 & 2019 & Ortalama & 2018 & 2019 & Ortalama \\
\hline 1 & 2.24 & 2.48 & 2.36 & 1.21 & 1.21 & 1.21 \\
\hline 2 & 2.25 & 2.37 & 2.31 & 1.19 & 1.20 & 1.19 \\
\hline 3 & 1.88 & 1.82 & 1.85 & 1.22 & 1.20 & 1.21 \\
\hline 4 & 2.14 & 2.26 & 2.20 & 1.13 & 1.14 & 1.13 \\
\hline 5 & 2.36 & 2.40 & 2.38 & 1.21 & 1.24 & 1.23 \\
\hline 6 & 1.82 & 2.15 & 1.98 & 1.18 & 1.20 & 1.19 \\
\hline 7 & 1.93 & 2.44 & 2.19 & 1.19 & 1.24 & 1.22 \\
\hline 8 & 2.46 & 2.55 & 2.50 & 1.15 & 1.13 & 1.14 \\
\hline 9 & 1.91 & 2.37 & 2.14 & 1.29 & 1.11 & 1.20 \\
\hline 10 & 1.71 & 1.98 & 1.84 & 1.25 & 1.19 & 1.22 \\
\hline Hatlar Ortalaması & 2.07 & 2.28 & 2.17 & 1.20 & 1.18 & 1.19 \\
\hline Zirve & 1.68 & 2.20 & 1.94 & 1.16 & 1.23 & 1.20 \\
\hline Noyanbey & 1.77 & 2.26 & 2.01 & 1.18 & 1.18 & 1.18 \\
\hline Standartlar Ortalaması & 1.72 & 2.23 & 1.98 & 1.17 & 1.21 & 1.19 \\
\hline Genel Ortalama & 2.01 & 2.27 & 2.14 & 1.20 & 1.19 & 1.19 \\
\hline
\end{tabular}


Çizelge 9. İncelenen özellikler arasındaki korelasyon katsayıları

\begin{tabular}{|c|c|c|c|}
\hline Değişken & Bağımlı Değișken & Korelasyon & Önemlilik Derecesi \\
\hline Protein Oranı (\%) & Nem Oranı (\%) & -0.3934 & 0.0057 \\
\hline Kuru Ağırlık (g) & Nem Oranı (\%) & -0.4325 & 0.0021 \\
\hline Kuru Ağırlık (g) & Protein Oranı (\%) & 0.5643 & $<.0001$ \\
\hline Kuru Hacim (ml) & Nem Oranı (\%) & -0.3826 & 0.0073 \\
\hline Kuru Hacim (ml) & Protein Oranı (\%) & 0.4572 & 0.0011 \\
\hline Kuru Hacim (ml) & Kuru Ağırlık (g) & 0.9510 & $<.0001$ \\
\hline Yaș Ağırlık(g) & Nem Oranı (\%) & -0.4333 & 0.0021 \\
\hline Yaș Ağırlık(g) & Protein Oranı (\%) & 0.5595 & $<.0001$ \\
\hline Yaș Ağırlık(g) & Kuru Ağırlık (g) & 0.9900 & $<.0001$ \\
\hline Yaș Ağırlık(g) & Kuru Hacim (ml) & 0.9325 & $<.0001$ \\
\hline $\operatorname{Islak} \operatorname{Hacim}(\mathrm{ml})$ & Nem Oranı (\%) & -0.4760 & 0.0006 \\
\hline Islak Hacim(ml) & Protein Oranı (\%) & 0.5139 & 0.0002 \\
\hline Islak Hacim(ml) & Kuru Ağırlık (g) & 0.9040 & $<.0001$ \\
\hline $\operatorname{Islak} \operatorname{Hacim}(\mathrm{ml})$ & Kuru Hacim (ml) & 0.8796 & $<.0001$ \\
\hline Islak Hacim(ml) & Yaş Ağırlık(g) & 0.9080 & $<.0001$ \\
\hline Su Alma Kapasitesi(g/tane) & Nem Oranı (\%) & -0.4052 & 0.0043 \\
\hline Su Alma Kapasitesi(g/tane) & Protein Oranı (\%) & 0.5335 & $<.0001$ \\
\hline Su Alma Kapasitesi(g/tane) & Kuru Ağırlık (g) & 0.9614 & $<.0001$ \\
\hline Su alma kapasitesi(g/tane) & Kuru Hacim (ml) & 0.9010 & $<.0001$ \\
\hline Su Alma Kapasitesi(g/tane) & Yaș Ağırlık(g) & 0.9886 & $<.0001$ \\
\hline Su Alma Kapasitesi(g/tane) & $\operatorname{Islak} \operatorname{Hacim}(\mathrm{ml})$ & 0.8906 & $<.0001$ \\
\hline Şișme Kapasitesi (ml/tane) & Nem Oranı (\%) & -0.4206 & 0.0029 \\
\hline Şişme Kapasitesi (ml/tane) & Protein Oranı (\%) & 0.3952 & 0.0054 \\
\hline Şişme Kapasitesi (ml/tane) & Kuru Ağırlık (g) & 0.5075 & 0.0002 \\
\hline Şișme Kapasitesi (ml/tane) & Kuru Hacim (ml) & 0.3968 & 0.0052 \\
\hline Şişme Kapasitesi (ml/tane) & Yaş Ağırlık(g) & 0.5393 & $<.0001$ \\
\hline Şişme Kapasitesi (ml/tane) & Islak Hacim(ml) & 0.7857 & $<.0001$ \\
\hline Șișme Kapasitesi (ml/tane) & Su Alma Kapasitesi(g/tane) & 0.5466 & $<.0001$ \\
\hline Şișme İndeksi(\%) & Protein Oranı (\%) & 0.5544 & $<.0001$ \\
\hline Şișme İndeksi(\%) & Kuru Ağırlık (g) & 0.8944 & $<.0001$ \\
\hline Șișme İndeksi(\%) & Kuru Hacim (ml) & 0.8634 & $<.0001$ \\
\hline Şişme İndeksi(\%) & Yaş Ağırlık(g) & 0.8950 & $<.0001$ \\
\hline Șișme İndeksi(\%) & Islak Hacim(ml) & 0.9003 & $<.0001$ \\
\hline Şişme İndeksi(\%) & Su Alma Kapasitesi(g/tane) & 0.8661 & $<.0001$ \\
\hline Şișme İndeksi(\%) & Șișme Kapasitesi (ml/tane) & 0.6143 & $<.0001$ \\
\hline
\end{tabular}

İncelenen korelasyon analizinde protein oranı ile; kuru ağırlık $\left(0.5643^{* *}\right)$, kuru hacim $\left(0.4572^{*}\right)$, yaș ağırlı $\left(0.5595^{* *}\right)$, ıslak hacim $\left(0.5139^{*}\right)$, su alma kapasitesi(0.5335**), şişme kapasitesi $\left(0.3952^{*}\right)$, şişme indeksi $\left(0.5544^{* *}\right)$ önemli pozitif ilişki tespit edilmiştir. Kuru ağırlık ile; kuru hacim $\left(0.9510^{* *}\right)$, yaş ağırlık $\left(0.9900^{* *}\right)$, ıslak hacim $\left(0.9040^{* *}\right)$, su alma kapasitesi (0.9614**), șișme kapasitesi $\left(0.5075^{*}\right)$, șişme indeksi arasında $\left(0.0 .8944^{* *}\right)$ önemli pozitif ilișki tespit edilmiștir. Benzer șekilde Elkoca ve Çınar (2015), yaș ağırlık, su alma kapasitesi, kuru hacim, yaş hacim ve şişme kapasitesinin kuru ağırlıkla önemli pozitif iliş̧ki gösterdiğini belirlemişlerdir. Atlı ve ark. (1994), kuru fasulyede kuru ağırlık arttıkça, yaş ağırlık, su alma kapasitesi, şişme kapasitesi değerlerinin artış gösterdiğini belirtmişlerdir.

Kuru hacim ile; yaş ağırlık $\left(0.9325^{* *}\right)$, ıslak hacim( $\left.0.8796^{* *}\right)$, su alma kapasitesi $\left(0.9010^{* *}\right)$, şişme kapasitesi $\left(0.3968^{*}\right)$ ve şişme indeksi $\left(0.8634^{* *}\right)$ önemli pozitif ilişki tespit edilmiştir. Yaş ağırlık ile; ıslak hacim $\left(0.9080^{* *}\right)$, su alma kapasitesi $\left(0.9886^{* *}\right)$, şişme kapasitesi $\left(0.5393^{* *}\right)$ ve şişme indeksi arasında $\left(0.8950^{* *}\right)$ önemli pozitif ilişki tespit edilmiştir. Islak hacim ile; su alma kapasitesi $\left(0.8906^{* *}\right)$, şişme kapasitesi $\left(0.7857^{* *}\right)$, şişme indeksi arasında $\left(0.9003^{*}\right)$ pozitif önemli bulunmuştur. Su alma kapasitesi ile; şişme kapasitesi $\left(0.5466^{* *}\right)$, şişme indeksi arasında (0.8661**) ve şişme kapasitesi (0.6143) önemli ilişki bulunmuştur. 


\section{Sonuç}

Kuru fasulye dünyada ve ülkemizde üretimi yapılan baklagil ürünü olup özellikle besin değerleri bakımından önemli bir yer tutmaktadır. Kuru fasulyede üretim artışı sağlamak için verimli ve kaliteli çeşitlerin geliştirilmesi ve ticarete konu olması gerekmektedir. $\mathrm{Bu}$ çalışmada Konya koşullarında farklı yılların kuru fasulye genotiplerinin fiziksel kalite özellikleri üzerine etkileri belirlenmiștir. Protein oranı, kuru ve yaş ağırlık, kuru hacim, ıslak hacim, yaş ağırlık, su alma kapasitesi, şişme indeksi, şişme kapasitesi ve su alma indeksi gibi kalite özellikleri bakımından yıllar ve genotipler arasında farklılıklar oluşmuştur. Araştırmada incelenen korelasyon analizinde tane irileştikçe protein oranı, kuru hacim, ıslak hacim, yaş ağırlık, su alma kapasitesi ve şişme kapasitesi artmıştır. Genotiplerin iki yıl ortalaması açısından değerlendirdiğimizde protein oranı bakımından 7 no'lu hatta en yüksek değer elde edilmiştir. Kuru ağırlık, kuru hacim, ıslak hacim, yaş ağırlık ve su alma kapasitesi bakımından 8 no'lu hatta en yüksek değerler elde edilmiştir. Şişme indeksi ve su alma kapasitesi bakımından 5 no'lu ve şişme kapasitesi bakımından ise 1 no'lu hatta da en yüksek değerler elde edilmiştir. İncelenen tüm özelliklerde iklim ve genotip faktörlerinin etkisinin önemli olduğu tespit edilmiștir. Kuru fasulye bölgemiz için oldukça önemli olup yeni çeşitlerin geliştirilmesi ülkemiz ve bölgemiz için oldukça önemlidir. Yeni çeşitlerin geliştirilmesi gıda sektörünün ihtiyacının karşılanması ile ülke ekonomisine katkı sağlayacaktır.

\section{Kaynaklar}

Anonim, (2009a). Faostat -Agriculture. http://faostat.fao. org/site/567/default.aspx\#ancor (29.06.2009).

Anonim, (2009b). Approved methodologies. www.leco.com /resources/approved_methods

Anonim, (2001). Tarımsal Değerleri Ölçme Denemeleri Teknik Talimatı. Yemeklik Tane Baklagiller. T.C. Tarım ve Köyişleri Bakanlığı, Koruma ve Kontrol Genel Müdürlügü̈, Tohumluk Tescil ve Sertifikasyon Merkezi Müdürlüğü, Ankara.

Anonim, (2014). JMP11, JSL Syntax Reference. SAS Institute. ISBN: 978-1-62959-560-3.
Anonim, (2018). Food and Agricultural Organization.(FAO) http://www.fao.org/faostat/en/\#data/QC. (Erişim tarihi: 17 Ocak 2018).

Anonim, (2017). Ürün raporu kuru fasulye. Tarımsal Ekonomi ve Politika Geliştirme Enstitüsü.(TEPGE).

Akçin, A. (1988). Yemeklik Tane Baklagiller. S.Ü. Ziraat Fakültesi. 8-43.Konya.

Atlı, A., Köksal, H., \& Dağ, A. (1994). Yemeklik Tane Baklagillerde Kalite Değerleri. Gıda Sanayii, 7(3), 44-48.

Balkaya, A. (1999). Karadeniz Bölgesindeki Taze Fasulye (Phaseolus Vulgaris L.) Gen Kaynaklarının Toplanması, Fenolojik ve Morfolojik Özelliklerinin Belirlenmesi ve Taze Tüketime Uygun Tiplerin Teksel Seleksiyon Yöntemi ile Seçimi Üzerinde Araștırmalar. Ondokuz Mayıs Üniversitesi Fen Bilimleri Enstitüsü Bahçe Bitkileri Ana Bilim Dalı, Samsun. Doktora Tezi.

Barros, M., \& Prudencio, S.H. (2016). Physical and Chemical Characteristics of Common Bean. Semina: Ciências Agrárias, 37 (2), 751-762.

Bolat, M. (2016). Türkiye'de Yemeklik Tane Baklagillerin Gelecek Eğilimlerinin Belirlenmesi Doktora Semineri. Ankara Üniversitesi Ziraat Fakültesi Fen Bilimleri Enstitüsü.

Bozoğlu, H., \& Gülümser, A. (1998). Kuru fasulyede bazi tarimsal özelliklerin genotip çevre interaksiyonlari ve stabilitelerinin belirlenmesi. Turkish Journal of Agriculture and Forestry, 24 (2000), 211-220.

Castañeda, M.A., Córdova, L., Gonzales, V., Delgado, A., Santacruz A., \& García. G. (2006). Respuestas fisiológicas, rendimiento y calidad de semilla en fríjol sometido a condiciones de estrés hídrico. INCI, 31 (6), 461-466.

Cengiz, B., Dağlıŏglu, O., \& Geçgel, Ü. (2008). Sakarya ve Eskişehir lokasyonlarında yetiştirilen bazı kuru fasulye çeşitlerinin kalite özellikleri. Türkiye 10. Gıda Kongresi; 21-23 Mayıs 2008, Erzurum.

Çalışkan, S., Aytekin, R.İ., Yağız, A.K., \& Yavuz, C. (2018). Bazı fasulye (phaseolus vulgaris l.) çeşitlerinde tam ve kısitlı sulama uygulamalarının tane kalitesi üzerine etkisi. Türk Tarım - Gıda Bilim ve Teknoloji Dergisi, 6 (12), 1853-1859.

Elkoca, E,, \& Çınar, T. (2015). Bazı kuru fasulye (Phaseolus vulgaris L.) çeşit ve hatlarının Erzurum ekolojik koşullarına adaptasyonu, tarımsal ve kalite 
özellikleri. Anadolu Tarım Bilimleri Dergisi, 30(2), 141-153.

Elgün, A., Türker, S., \& Bilgiçli, N. (2005). Tahıl ve ürünlerinde analitik kalite kontrolü. Selçuk Üniv. Ziraat Fakültesi Gıda Mühendisliği, Konya.

Fageria, N,K., Melo, L.C., Ferreira, E.P.B., Oliveira, J.P., \& Knupp, A.M. (20149. Dry matter, grain yield, and yield components of dry bean as influenced by nitrogen fertilization and rhizobia. Communications in Soil Science and Plant Analysis, 45, 111-125.

Ferreira, C.D., Ziegler, V., Paraginski, R.T., Vanier, N.L., Elias, M.C., \& Oliveira, M. (2017). Physicochemical, antioxidant and cooking quality properties of longterm stored black beans: effects of moisture content and storage temperature. International Food Research Journal, 24(6), 2490-2499.

Gathu, W.E., \& Njage, P.M.K. (2012). Physical characterization of new advanced drought tolerant common bean (Phaseolus vulgaris) lines for canning quality. American Journal of Food Technology, 7(2), 22-28.

Kaçar, O., Çakmak, F., Çöplü, N., \& Azkan, N. (2004). Bursa koşullarında bazı kuru fasulye çeşitlerinde (Phaseolus vulgaris L.) bakteri aşılama ve değișik azot dozlarının verim ve verim unsurları üzerine etkisinin belirlenmesi. Uludağ Üniversitesi Ziraat Fakültesi Dergisi, 18(1), 207-218.

Karaca, Ü. (2010). Konya Yöresinde Yetiștirilen Kuru Fasulyeden İzole Edilen Rhizobium Bakterilerinin Etkinliklerinin Belirlenmesi. Selçuk Üniversitesi Fen Bilimleri Enstitüsü Doktora Tezi.

Kahraman, A. (2008). Konya Bölgesinde Yetiștirilen Bodur Kuru Fasulye (Phaseolus vulgaris L.) Popülasyonlarının Genetik Farklılıklarının ve Bazı Kalite Özelliklerinin Belirlenmesi. Yüksek Lisans Tezi Selçuk Üniversitesi Fen Bilimleri Enstitüsü Tarla Bitkileri Anabilim Dalı.

Kınacı, G., Akın, R., \& Kınacı, E. (2008). Farklı sulama rejimlerinin kuru fasulyenin(phaseolus vulgaris l.)fiziksel kalite özellikleri üzerine etkileri C.B.Ü. Fen Bilimleri Dergisi , 4(2), 179-186.

Montoya, C.A., Leterme, P., Victoria, N.F., Toro, O., Souffrant, W.B., Beebe, S., \& Lalles, J.P. (2008). Susceptibility of phaseolin to in vitro proteolysis is highly variable across common bean varieties (Phaseolus vulgaris). Journal Agricultural of Food Chemistry, 56(6), 2183-2191.
Nciri, N., El Mhamdi, F., Ismail, H.B., Mansour, A.B., \& Fennira, F. (2015). Physical properties of three white bean varieties (phaseolus vulgaris l.) grown in tunisia. Journal of Applied Science and Agriculture, 9(11), 195-200.

Nunez Barrios, A., Hoogenboom, G., \& Nesmith, D.S, (2005). Drought stress and distribution of vegetative and reproductive traits of a bean cultivar. Scientia Agricola (Piracicaba, Braz.), 62, 18-22.

Özbekmez, Y. (2015). Ordu Ekolojik Koşullarında Bazı Kuru Fasulye (Phaseolus vulgaris l.) Çeşit ve genotiplerinin Verim, Verim Öğeleri ile Tohum ve Teknolojik Özelliklerinin Belirlenmesi. Ordu Üniversitesi Fen Bilimleri Enstitüsü, Yüksek Lisans Tezi.

Saha, S., Singh, G., Mahajan, V., \& Gupta, H.S. (2009). Variability of Nutritional and Cooking Quality in Bean (Phaseolus Vulgaris L.) As A Function of Genotype. Plant Foods Human Nutrition, 64(2), 174180.

Sözen, Ö., Karadavut, U., \& Akçura, M. (2017) Determination of the some yield components of dry bean (Phaseolus vulgaris l.) genotypes in different environments. International Journal of Agriculture and Environmental Research, 3(5), 3755-3769.

Singh, P.S. (2001). Broadening The Genetic Base of Common Bean Cultivars. Crop Science, 41(6), 16591675.

Şehirali, S. (1988). Yemeklik Dane Baklagiller. A.Ü. Ziraat Fakültesi Yayınları 1089, Ders Kitabı 314. Ankara.

Șehirali, S., \& Atll, A. (1993). Fasulye (Phaseolus vulgaris L.)' de Pișme özellikleri. Tekirdağ Ziraat Fakültesi Yayınları, No: 161

Şehirali, S., Özçelik, H., \& Yorgancılar, Ö. (1994). Kuru tane olarak tüketilen bodur fasulye gen kaynaklarının karakterizasyonu üzerinde araștırma. 1. Tarla Bitkileri Kongresi, Bitki Islahı Bildirileri 2: 134-140, 25-29 Nisan, Bornova-İzmir.

Ülker, M. (2008), Orta Anadolu Ekolojik Şartlarında Yetiştirilen Fasulye (Phaseolus Vulgaris L.) Genotiplerinin Bazı Tarımsal ve Kalite Özelliklerinin Belirlenmesi, Yüksek Lisans Tezi, Selçuk Üniversitesi Tarla Bitkileri Anabilim Dalı, Konya. 
Wani, I.A., Sogi, D.S., Wani, A.A., \& Gill, B.S. (20179. Physical and cooking characteristics of some Indian kişne bean (Phaseolus vulgaris L.) cultivars. Journal of Saudi Society of Agricultural Sciences, 16, 7-15. 